\title{
Managers, not markets
}

Neoliberal policy owes less to the ideology of free-markets than it does the planning techniques born in Cold War America.

Sahil Jai Dutta, Samuel Knafo, Richard Lane, Steffan Wyn-Jones

\section{A tale of two think tanks}

One enduring myth about the triumph of neoliberalism ${ }^{1}$ is the role of the Mont Pelerin Society (MPS). Its founding members and 1947 'Statement of Aims' are thought to have laid the foundations for an ideological hegemony that has defined politics for the last four decades.

But look beyond the rhetoric of Friedrich Hayek, Milton Friedman and their MPS colleagues and it's actually a different think tank that matters. The Cold War RAND Corporation, founded in 1948 by the US Airforce and weapons manufacturer Douglas Aircraft, incubated the tools and techniques that encoded neoliberalism into contemporary life. Over the decades that followed the second world war, researchers at RAND turned the study of planning and managing warfare into a blueprint for planning and managing society ${ }^{2}$.

Unlike the highly idealised, abstract principles of freedom that occupied the MPS, RAND was in the business of constructing tools policymakers could actually use. RAND developed a celebrated gallery of twentieth century intellectuals (including 23 Economic Nobel Prizewinners) who laid the technical foundation for contemporary policymaking.

Many of these researchers were mathematicians or Keynesian economists. Though ferociously opposed to soviet socialism, their vision was less about free markets than it was about planning. RAND researchers recognised the market as something to be organised for the purpose of making policy not the opposite, as the MPS idealists imagined. That in reality the reforms made by neoliberal policymakers never matched the free-market theory of Hayek and his colleagues is well known. Yet too often the mismatch is explained because of a partial or failed implementation of that aim for market rule. Rather than markets and the MPS, we should look to the RAND-based, managerial roots of neoliberal policy.

By putting the ideological rhetoric of neoliberalism to one side, and focussing instead on the technical apparatus of public management, we can get a clearer grasp of how neoliberal policies are made and how they can be resisted.

\section{Remaking Management}

It is easy to conflate this focus on the managerial roots of neoliberalism with the familiar idea of technocratic governance. Whether central bank independence or EU fiscal compatibility rules, neoliberal governance has always made use of bodies with limited democratic oversight. But the managerial roots of neoliberalism are not simply an extension of Weber's iron-cage, bureaucratic rationality. Instead, RAND re-invented management practices, traditionally focused on control, to turn them into tools for decision-making. This is best understood by contrasting neoliberal managerialism 
with what went before.

A management revolution: From scientific management to neoliberal managerialism

\begin{tabular}{|l|l|l|}
\hline & Scientific management & Neoliberal managerial governance \\
\hline Key period & 1880s - 1930s & 1940s - 1990s \\
\hline Key institutions & Ford, GM & RAND \\
\hline Key targets & Improving efficiency & Policymaking \\
\hline Key expertise & Engineers, accountants & Mathematicians, economists \\
\hline Key focus & Micro, producer level & Macro, strategic level \\
\hline Key goal & Optimisation: absolute gains & Gaming: relative gains \\
\hline Information & Measurement: backward looking & Modelling: predictive and forward looking \\
\hline $\begin{array}{l}\text { Budgeting } \\
\text { approach }\end{array}$ & Accounting: backward looking & Economics: predictive and forward looking \\
\hline
\end{tabular}

Before the RAND-centred revolution, there was the scientific management of nineteenth century US manufacturing. This was the period in which the belief in and intense focus on the promise of management to deliver social improvement began. 'Scientific managers' trained as engineers and accountants were expected to improve factory efficiency through better measurement, benchmarking and standardisation. They were technicians deeply involved in operations and working close to the ground, often organising the micro processes of production. But they had no role in the macro questions of overall corporate strategy. Instead, a class of administrators at the top of corporations set broad organisational policies and objectives, which managers were tasked with carrying out as efficiently as possible.

What developed at RAND was far more ambitious than the programmes of Frederick Taylor, Henry Ford and the American industrial managers who followed them. In contrast to relying on an art of administration to set strategic goals, RAND wanted to develop a science of top-level decision-making: rigorous, formalised and technical. The technologies of management that emerged were designed to mathematically model executive decisions and ground them in apparently objective facts.

It was an ambition that drew not from the needs of profit-maximising private industry, but from the necessity of organising and refining America's cold war strategy. RAND had been established precisely to capitalise on the innovations in statistical analysis and military planning made during the second world war. ${ }^{3}$ Weapons systems analysis (soon renamed systems analysis) was its key development. And from this sprang many of the neoliberal managerial techniques that revolutionised the public sector over the second half of the twentieth century. Understanding the key features of managerial governance is crucial if progressives are to decode neoliberalism.

\section{Systems analysis and the birth of neoliberal managerialism}

Key to systems analysis was its reliance on modelling social systems and its strategic framing of decision-making.

Mathematical modelling was used to predict and compare the effectiveness of different possible courses of action. At first, this was about determining military strategy: choosing what weapons systems to deploy and where. Later, these models were repurposed for civilian planning. They allowed top-level 
strategists to experiment with manipulating different parameters in order to establish the potential payoffs of different strategies.

Crucial to this was the integration of linear and dynamic programming, sequential analysis and Bayesian statistics. It is no coincidence that the early architects of this kind of modelling were not engineers and technicians but abstract mathematicians like Jon von Neumann and Warren Weaver.

In translating social and political concerns into brute numbers, managerial governance revolutionised quantification. While the scientific managers of Taylorism had put a huge emphasis on measurement and numbers, systems analysis went well beyond anything that could be directly measured. It targeted aspects that could barely be observed, let alone counted. Though mathematically rigorous, this often involved an array of creative substitutions, using specific data as a means of assessing something far bigger, more diffuse, and harder to quantify.

A notorious example was the use of body counts to assess the performance of the US Army in the Vietnam $\mathrm{War}^{4}$. But the emphasis on constructing social indicators as a means to assess policymaker performance and feed policymaking has endured ever since.

This is seen today in the New Public Management reforms of the public sector. DEFRA, for example, uses a biodiversity offsetting metric to assess the 'quality' of natural habitats and land. The Prevent programme, meanwhile, collapses and transforms a multitude of social issues into a tick-box assessment of dangerous 'radicalisation'.

These metrics are well known to be imperfect. They only become useful for policymaking when augmented by the second feature of systems analysis: Game Theory. The Game Theory vision of a world of self-interested, competitive actors is often thought to be central to neoliberal ideology. But again, the focus on broad-brush ideology misses its importance. What matters more is what Game Theory meant for management.

It framed organisational management in strategic terms. In contrast to Taylorist management, optimisation wasn't the key problem managers were trying to solve, gaming was. Game Theory and its offshoot Rational Choice theory were both incubated at RAND and together radically remade what was expected of top-level managers. This was because they produced hugely counter-intuitive insights about strategy. Game Theory modelling 'proved' that what might be the best course of action in theory, could end up being suboptimal in practice when a competitor's actions were accounted for. Just think of the Prisoners Dilemma: though co-operation would be optimal, the assumption of a gaming competitor casts the suboptimal, second-best option (cheat the opponent) as the most sensible choice. Managers had to redesign incentive structures around this notion of strategic, gaming individuals.

\section{Information management}

In trying to pull the expertise of complex modelling and strategic management out of the domain of wargaming and into civilian life, RAND researchers recast the notion of 'information'. The managerial makeover of information was to prove crucial to the way frontline public service workers and users would later be compelled to generate huge reams of 'data' to feed back into organisational management. The reliance on data about performance to make policy (or strategic) decisions meant an explosion of audits, policy evaluations and performance management that were meant to give managers a perspective on the problems they faced. 
Fitting what became a broader frustration with the 'remote' feel of postwar welfare state services, the idea was that the entire organisation - be it a hospital or a police force - and its users possessed information that could feed into better decision making.

This information was then organised centrally through budgeting and in particular the updated technique of cost-benefit analysis (CBA). CBA made budgeting the centre of planning for the first time.

In doing so budgeting was transformed from an accountant's approach that tracks back in time, reporting resources used over a financial year, to a more forward-looking economist's perspective. This meant repurposing CBA, which had emerged in the 1930s as a general formula to help planners organise large-scale infrastructure projects, into a more systematic means of comparing and evaluating proposed projects, expenditures and regulatory activities.

CBA became a template to reflect on different policy options and remains so today. Though its insights are readily ignored (HS2, for example is repeatedly shown to be a less efficient spend than other options), it is nonetheless the framework by which policy implementation is conceptualised. Budgeting and decision making, previously distinct, were brought together.

\section{From warfare to welfare}

The technical foundation had been laid at RAND but it took Robert McNamara's appointment as Secretary of Defence in 1960 to bring Cold War planning to the welfare state. McNamara took various RAND researchers with him into the public sector. Especially important were the economists Charles Hitch, David Novick and Alain Enthoven (who would go on to script Margaret Thatcher's early versions of the 'internal market' in the NHS). Together they helped establish the Planning, Programming, and Budgeting System (PPBS). This was first used by McNamara in the defence department, but would later be redeployed in areas like health care, education, welfare and urban planning.

The need for analytical expertise that came with PPBS drove the requirement for think tanks and research institutions whose funding and overt ideological orientation were provided by Hayek and his financial backers. Yet their influence can be best read in the way they helped transform Public Policy into a highly technical discipline with specialist schools.

Though PPBS never delivered on its promise of rationally organising and optimising the social sector, similar budgetary planning techniques endured. In just the same way military strategists tried to decide on different weapons systems, these planning techniques later provided a way to decide, for example, what services a clinical commissioning group should 'purchase' to meet its region's expected health needs.

Indeed, the rhetoric of technocratic management and cold data analysis underpinned the depoliticisation of discussion around public sector management that we witness in the neoliberal age. By insisting governance was simply a data-led assessment of performance, responsibility for the continued failures could be passed onto lower orders, while responsibility for decision-making was reinforced at the top.

The deployment of the new management science, with its suite of metrics and decision technologies enabled a new form of control at a distance. Top managers cast themselves as neutral arbiters, who 
simply allocated resources to those who performed. And if that meant a hospital closing, or a university department shutting down, so be it. In that sense, the managed competition ${ }^{5}$ that characterises neoliberalism belongs firmly within a framework intended to empower managers, rather than enforce 'the market'.

From the beginning, proponents of systems analysis had doubted the ability of market-like mechanisms to adequately assess the information it was given. Perhaps head teachers or hospital chiefs would exaggerate their costs and disrupt the proper functioning of an internal market?

For that reason, public sector reform was built on new techniques of costing and performance assessment, so as to compensate for the inability of the market to correctly assess needs and costs. The point was not to 'let' competition choose winners and losers. Instead top managers expected to arrive themselves at a verdict on what performance indicators really meant and what their implications should be. The contradiction between this managed competition and the Hayekian scepticism of planning is stark.

\section{Social movements aren’t (just) social}

Progressive voices often look longingly at the MPS as a model to follow. With faith in neoliberal principles eroding, there is a wish for us too to have a body of theory ready to deploy. But the managerial story shows how neoliberal practices were encoded into the public sector first in 1960s America. Whatever the ideological commitments developed at the MPS, the actual lived practice of neoliberalism owes much more to the technical work done at RAND.

It is an insight that muddies the story of the so-called shift that took place from the Keynesian post-war consensus to 'free-market' neoliberalism in the 1970s-1980s. It was not that voters gradually gave up on one established economic model and embraced something new. The social shift was less significant than the technical one.

Progressives looking to construct a new normal must see technical innovation as key to the reconstruction of public and private institutions. Management technologies are not neutral, but neither are they wholly determined by the political context within which they developed. Rather, they are central to reforming the political contexts by enabling consensus building around shared targets, the relocation of decision making and control, and the reconfiguration of broader strategic aims. If a radically reformist party were to take office at the next election, it would need to draw on a new body of technical planning instruments to respond to intersecting ecological, economic and social challenges.

At a national level, basing macroeconomic decision-making upon ecological macroeconomic models ${ }^{6}$ could challenge current supply-side goals that presume rational gaming behaviour and legitimate the objectivity of current managerial planning. Going beyond a post-Keynesian focus on sustainable consumption, and 'green' investment, this would begin by shifting indicators towards social welfare and equitability. The European Commission's 'Beyond GDP' initiative could provide one starting point here.

At the institutional level, this shifting focus towards social welfare could be reinforced through two further developments. First, the current techniques of centralised managerial planning - targets, scenario development, dashboarding - could be replaced by sector-specific accountability frameworks, developed with unions so workers themselves create the criteria of assessing their sector. Deployed at the same time as a democratic drive to flatten management hierarchies along lines perhaps most famously laid out in the 'Valve Employee Handbook', this would enable worker ownership of decision 
making design and control.

Second, alternative budget allocation mechanisms could be used for funding allocation towards broad welfare goals. One possibility could be to expand quality of life metrics (QALYs) already used by NICE as a budget allocation mechanism in the NHS. Currently used to measure only health outcomes, a left managerial programme could build on existing attempts to expand QALYs through the inclusion of broader, non-clinical welfare factors and thereby leverage this technology into non-health budgetary planning. For example, in opposition to Universities Minister Sam Gyimah's desire to develop a 'go.compare.the.university.com' assessment that reduces educational quality to future earning potential, an expanded QALY could be used to assess degrees in terms of increasing overall social welfare.

Given its managerial origin, countering neoliberalism means developing a programme for left management. This necessitates going beyond simply ownership reform. Instead, a left management programme would begin from the current suite of managerial technologies and simultaneously challenge and retrofit these to affect the institutional change necessary to address our most pressing concerns.

\footnotetext{
${ }^{1}$ We discuss mainly the application of the term neoliberalism to the West. The term 'neoliberalism' is often used to describe e.g. Arab states' relations with the IMF over the last 30 years, the policies that underlay the so-called Washington Consensus and the way that structural adjustment programs were implemented in Latin America, Asia and Africa through the 1990s. That is not the focus here.

2 Knafo et al., 'The Managerial Lineages of Neoliberalism'.

${ }^{3}$ Amadae, 'Rationalizing Capitalist Democracy'.

${ }^{4}$ Waitzkin, 'The Strange Career of Managed Competition'.

${ }^{5}$ Enthoven, 'The History and Principles of Managed Competition'.

${ }^{6}$ Rezai \& Stagl, 'Ecological macroeconomics: Introduction and review'.
} 